\title{
Prakiraan Usia Gigi Menggunakan Standar Blenkin (Modifikasi Metode Demirjian) pada Anak-Anak Etnik Jawa di Kabupaten Jember
}

(Tooth Age Estimation Using the Blenkin Standard (Modified Demirjian Method) on Ethnic Javanese Children in Jember District)

\section{Dwi Kartika Apriyono}

Laboratorium Odontologi Forensik, Bagian Biomedik, Fakultas Kedokteran Gigi Universitas Jember

\begin{abstract}
Abstrak
Usia kronologis dan gigi merupakan aspek penting dari estimasi usia gigi. Keduanya memiliki hubungan dekat. Usia kronologis mencerminkan usia gigi, dan sebaliknya. Estimasi usia gigi bertujuan untuk menyediakan data di bidang kedokteran gigi dengan rentang usia gigi yang akurat. Untuk mendapatkan nilai estimasi usia gigi yang akurat, diperlukan suatu metode estimasi yang memiliki standar deviasi serendah mungkin dan divalidasi pada kelompok populasi tertentu dari suatu individu. Metode Demirjian merupakan metode yang sering digunakan dalam pendugaan usia gigi. Metode ini menggunakan tahapan klasifikasi tujuh gigi permanen rahang bawah kiri menggunakan radiografi panoramik. Penerapan metode Demirjian di beberapa negara mendapatkan hasil yang berbeda-beda sehingga disarankan untuk melakukan penyesuaian terhadap metode ini. Standar Blenkin merupakan penyesuaian dari metode Demirjian yang mengubah skor tahap kematangan $0-\mathrm{H}$ menjadi 1-8 dan menggunakan rumus regresi untuk menghitung usia gigi. Tujuan dari penelitian ini adalah untuk menilai estimasi usia gigi menggunakan standar Blenkin pada anak etnis Jawa di wilayah Jember. Penelitian ini menggunakan desain penelitian deskriptif analitik. Sampel yang digunakan dalam penelitian ini adalah radiografi panoramik yang diperoleh dari subjek yang telah memenuhi kriteria penelitian sebanyak 70 sampel yang terdiri dari 29 laki-laki dan 41 perempuan dengan rentang usia 6-12 tahun. Sampel dikelompokkan berdasarkan jenis kelamin dan dibagi menjadi 7 kelompok berdasarkan usia kronologis. Setiap gigi sampel dihitung menggunakan standar Blenkin. Standar Blenkin menunjukkan perbedaan yang tidak signifikan dengan perbedaan usia sekitar -0,22 tahun untuk anak laki-laki dan 0,03 tahun untuk anak perempuan (underestimate).
\end{abstract}

Kata kunci: Blenkin standar, estimasi usia gigi, kronologi usia gigi

\section{Abstract}

Chronological and dental age are necessary aspects of dental age estimation. Both have a close relationship. Chronological age reflects the age of the tooth, and vice versa. Dental age estimation aims to provide the data in the field of dentistry with an accurate dental age range. In order to get the value of an accurate estimate of dental age, needed a method of estimation that has a standard deviation as low as possible and validated in a specific population groups of an individual. Demirjian method is a method frequently used in the dental age estimation. It uses the classification stages of the seven permanent teeth of mandibular left side using panoramic radiographs. Application of its method in some countries showed vary results so it needed adjustment. Blenkin standard is an adjustment of its method that changes the score of maturity stages $0-\mathrm{H}$ to $1-8$ and calculate the dental age by regression formula. The study aimed to assess the dental age estimation using Blenkin standard on children of Javanese ethnic in Jember region. This was an analytic descriptive study design. The samples were panoramic radiographs. The subjects were 70 samples consisting of 29 boys and 41 girls with an age range 6-12 years, and they were divided into 7 groups based on chronological age. Each tooth of the sample was calculated using Blenkin standard. The Blenkin standard showed non-significant difference with the age difference in the amount of approximately -0.22 years for boys and -0.03 years for girls (underestimation).

Keywords: Blenkin standard, dental age estimation, dental age chronological

Korespondensi (Correspondance) : Dwi Kartika Apriyono. Fakultas Kedokteran Gigi Universitas Jember. Jl. Kalimantan 37 Jember. Telp: (0331) 333536. Email: dapriyono@gmail.com

Prakiraan usia seseorang menggunakan sarana gigi seringkali dilakukan karena gigi merupakan material biologis yang paling tahan terhadap perubahan lingkungan. Dari semua jaringan keras yang terdapat pada tubuh manusia, gigi memiliki kelebihan yaitu stabil dan tidak mudah rusak dalam penyimpanan.' Beberapa faktor yang berpengaruh dalam prakiraan usia gigi individu yang menimbulkan variasi dalam prakiraan usia gigi antar individu. Genetik merupakan salah satu faktor yang paling berpengaruh dalam variasi waktu dan kecepatan perkembangan gigi. Faktor-faktor lain seperti: usia, jenis kelamin, ras, dan etnik juga berpengaruh dalam prakiraan usia gigi individu. Selain itu, terdapat juga faktor non genetik dan lingkungan yang diperkirakan mempunyai pengaruh dalam perkembangan gigi meskipun pengaruhnya kecil.' Etnik merupakan salah faktor yang mempunyai pengaruh penting dalam proses prakiraan usia gigi individu. Masing-masing etnik mempunyai karakteristik pertumbuhan dan perkembangan gigi yang berbeda-beda.

Prakiraan usia gigi bertujuan untuk menyediakan data dibidang kedokteran gigi dengan rentang usia gigi yang akurat dalam profil biologinya. Jika rentang usia gigi terlalu besar, hal itu tidak akan membantu secara tepat dalam memperkirakan usia gigi dengan rentang usia gigi tertentu. Supaya mendapatkan nilai yang tepat, metode yang digunakan harus memiliki standar deviasi serendah mungkin dan divalidasi dalam kelompok populasi yang spesifik dari sebuah 
individu. ${ }^{2}$ Sebuah studi harus memiliki rentang usia gigi tertentu dan harus representatif untuk menilai sebuah tahap pembentukan gigi mulai tahap awal perkembangan hingga tahap akhir. Tingkat maturasi dari sistem jaringan yang berbeda menentukan usia fisiologisnya. ${ }^{3}$ Aspek penting dalam perkiraaan usia gigi adalah menggunakan prakiraan usia gigi lebih dari satu metode dan melakukan pengukuran dan kalkulasi yang berulang-ulang untuk mendapatkan prakiraan usia gigi yang tepat. ${ }^{4}$

Metode prakiraan usia gigi yang paling sering digunakan adalah metode Demirjian. Metode ini lebih mudah dan akurat karena menggunakan indikator maturasi gigi yaitu tahapan pembentukan gigi permanen mulai dari pembentukan mahkota hingga penutupan akar gigi melalui foto panoramik. Metode ini menggunakan sistem skoring yang disebut Standar Demirjian (Demirjian Maturation Score). Penentuan standar dalam metode ini menggunakan sampel penelitian anak-anak Perancis-Kanada yang termasuk dalam ras Kaukasoid. Penggunaan metode Demirjian di beberapa negara dengan etnik/ras yang berbeda menunjukkan hasil yang sangat bervariasi. ${ }^{2}$ Hasil yang bervariasi tersebut dimungkinkan juga disebabkan faktor lingkungan seperti status sosial ekonomi dan nutrisi. ${ }^{5}$ Oleh karenanya dianjurkan untuk melakukan penyesuaian dalam pemberian skor maturasi untuk setiap tahap kalsifikasi gigi bila menggunakan metode ini pada populasi yang berbeda. ${ }^{3}$ Salah satu peneliti yang telah mengembangkan metode Demirjian adalah Blenkin. Blenkin telah membuat penyesuaian berupa standar Blenkin yang berbeda dari standar yang digunakan oleh Demirjian. Standar ini disebut juga simple Maturation Score. Standar ini telah diterapkan pada populasi anak-anak Sydney Australia dan mendapatkan hasil prakiraan usia gigi yang lebih akurat dibandingkan menggunakan standar Demirjian.

Tujuan dari penelitian ini adalah menganalisis prakiraan usia gigi mengunakan standar Blenkin yag merupakan modifikasi metode Demirjian pada anak-anak etnik Jawa di Jember.

\section{METODE PENELITIAN}

Desain penelitian yang digunakan dalam penelitian ini adalah deskriptif analitik. Kriteria subyek penelitian yaitu : anak laki-laki dan perempuan berusia 6-12 tahun, berasal dari etnik Jawa hingga 2 generasi diatasnya, lahir dan berdomisili di Kabupaten Jember, tidak memiliki riwayat penyakit sistemik, gangguan hormonal, kelahiran prematur, hormonal, kelainan kongenital dan tidak pernah/ sedang menjalani radioterapi dan kemoterapi, kondisi rongga mulut normal yaitu tidak adanya abnormalitas pada jumlah gigi permanen rahang bawah kiri, merupakan pasien baru yang akan dilakukan perawatan ortodonsia di bagian Ortodonsia RSGM FKG
Universitas Jember. Besar sampel yang digunakan adalah keseluruhan sampel yang diperoleh dari subyek penelitian yaitu sebesar 70 sampel yang terdiri dari 29 sampel laki-laki dan 41 sampel perempuan dengan rentang usia mulai dari 6,00 tahun hingga 12,99 tahun. Penelitian ini dilakukan di Bagian Ortodonsia RSGM Universitas Jember dan Laboratorium Klinik Parahita Jember. Alat yang digunakan dalam penelitian ini adalah: Foto rontgen panoramik merk Texpano 77 seri Hi 0414, Notebook merk HP mini 210-1006TU black, Alat ukur tinggi badan dan berat badan manual analog merk SMIC tipe z† 120

\section{Cara Menghitung Usia Kronologis}

Usia kronologis dihitung berdasarkan waktu kelahiran dan waktu pengambilan foto rontgen panoramik (tanggal, bulan, dan tahun). Jumlah hari dalam rentang waktu kelahiran hingga waktu pengambilan foto rontgen panoramik dihitung dan kemudian membagi jumlah hari yang sudah diketahui dengan 365 hari.

\section{Penggunaaan Metode Demirjian}

Metode Demirjian merupakan metode prakiraan usia gigi berdasarkan pada delapan tahapan dari perkembangan 7 gigi permanen rahang bawah kiri melalui foto rontgen panoramik memberinya skor mulai dari "A" hingga "H". Delapan tahapan tersebut merupakan hasil dari kalsifikasi masing-masing gigi, mulai dari kalsifikasi mahkota dan akar hingga penutupan apeks gigi. Demirjian membedakan subyek anak laki dan anak perempuan. Semua skor untuk masing-masing gigi dijumlahkan dan dihitung. Kemudian dikonversi secara langsung ke dalam usia gigi menggunakan tabel konversi. Setiap tahapan maturasi untuk 7 gigi rahang bawah kiri memiliki bobot penilaian yang berbedabeda (gambar 1). ${ }^{3}$

\section{Penggunaan Standar Blenkin}

Standar Blenkin diperkenalkan oleh Matt Blenkin yang merupakan modifikasi standar yang digunakan pada metode Demirjian et al. Standar Blenkin ini disebut dengan Simple Maturasi Score (SMS). Skor ini digunakan pertama kali pada populasi anak-anak Sydney Australia. Standar skor ini merupakan sistem pemberian skor yang sederhana untuk menilai masing-masing tahapan maturasi dari 7 gigi rahang bawah kiri yang digunakan oleh Demirjian et al. Pemberian skor abjad-angka tahapan maturasi $\mathrm{O}$ sampai $\mathrm{H}$ dikonversi menjadi pemberian skor maturasi angka 1 sampai 8. Skor maturasi (x) diperoleh dari penjumlahan skor yang diberikan pada masing-masing tahap kalsifikasi gigi. Prakiraan usia (y) diperoleh dengan menggunakan rumus regresi' :

Laki-laki :

$\mathrm{y}=-2.042579201+0.416441557^{*} \mathrm{x}-$ $0.009307122 * x 2+0.000128194 * x 3$ 
Perempuan :

$\mathrm{y}=\quad-1.914675804+0.421823224 * x-$ $0.010273636 * x 2+0.000141442 * \times 3$.

Tabel 1. Konversi tahapan maturasi gigi abjad-angka ke skor maturasi angka menurut Blenkin (2009)

\begin{tabular}{cc}
\hline Tingkat Demijian & Skor Maturitas \\
\hline O & 0 \\
A & 1 \\
B & 2 \\
C & 3 \\
D & 4 \\
E & 5 \\
F & 6 \\
G & 7 \\
H & 8 \\
\hline
\end{tabular}

\section{Cara Penilaian Maturasi Gigi}

Semua penilaian sampel dilakukan berdasarkan kriteria yang ditetapkan oleh Demirjian et al. dengan menggunakan standar Blenkin. Sampel penelitian dikelompokkan berdasarkan jenis kelamin dan usia kronologis. Usia kronologis yang sudah diketahui dibagi menjadi 7 kelompok usia yaitu 6-6.99 tahun, 7-7.99 tahun, 8-8.99 tahun,
9-9.99 tahun, 10-10.99 tahun, 11-11.99 tahun, dan 12-12.99 tahun. Pemberian skor pada masing-masing sampel dengan memberi nilai pada tujuh gigi kiri bawah. Interpretasi tingkat maturasi dengan metode Demirjian :

a. Setiap gigi dinilai pada skala 8 tahapan kalsifikasi gigi mulai dari $\mathrm{A}$ sampai $\mathrm{H}$ tergantung pada tahap kalsifikasinya

b. Mengkonversi nilai tahapan kalsifikasi gigi A-H setiap sampel yang sudah diketahui ke dalam skor maturasi 0-8.

c. Skor maturasi setiap tahapan kalsifikasi gigi dari tujuh gigi dijumlah dan jumlah skornya memberikan perhitungan maturasi gigi sampel.

d. Usia gigi diperoleh dengan cara menghitung skor maturasi gigi sampel menggunakan rumus regresi prakiraan usia gigi menurut Blenkin sesuai jenis kelamin subyek.

Setiap sampel dilakukan $2 x$ penghitungan dengan rentang waktu 2 minggu untuk kalibrasi. ${ }^{5}$

Data yang diperoleh dari penilaian usia gigi dianalisis menggunakan Paired t-test untuk uji kemaknaan perbandingan usia kronologis dan usia gigi menggunakan program SPSS versil 6 .

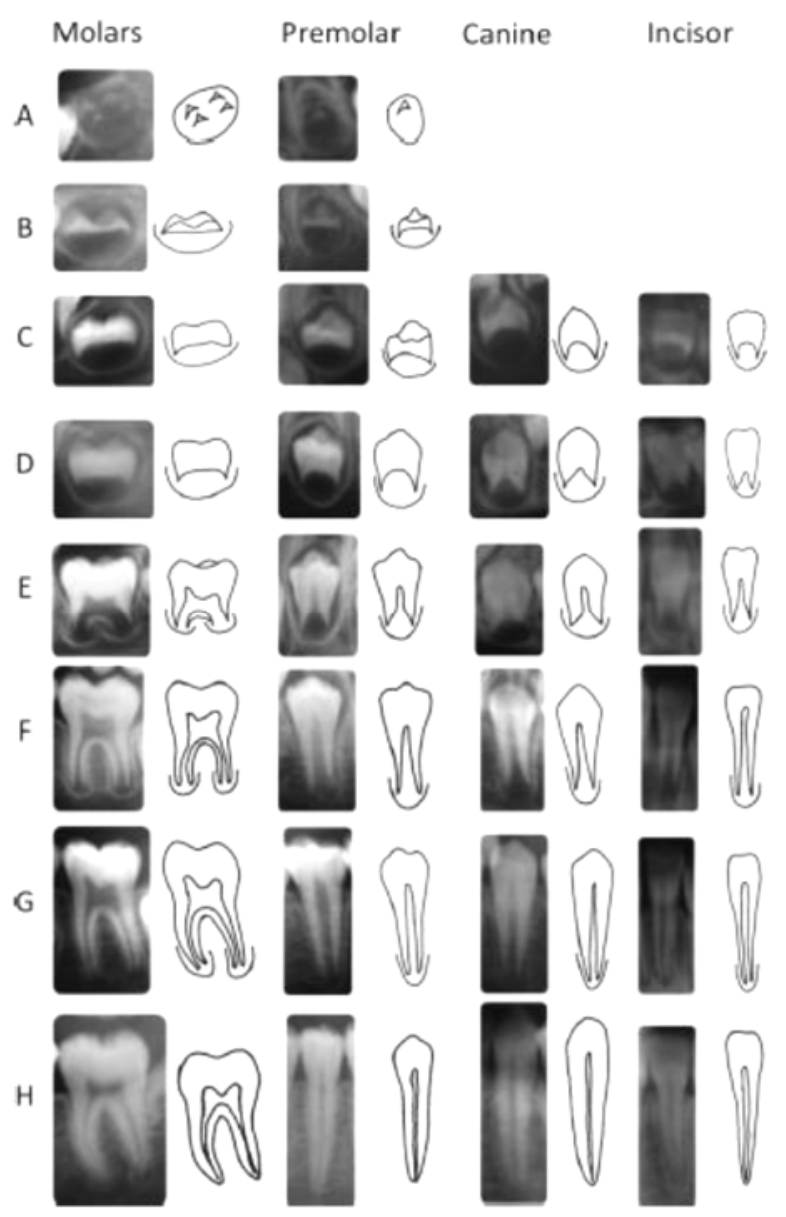

Gambar 1. Tahap kalsifikasi gigi permanen menurut Demirjian et al. (1973).3 


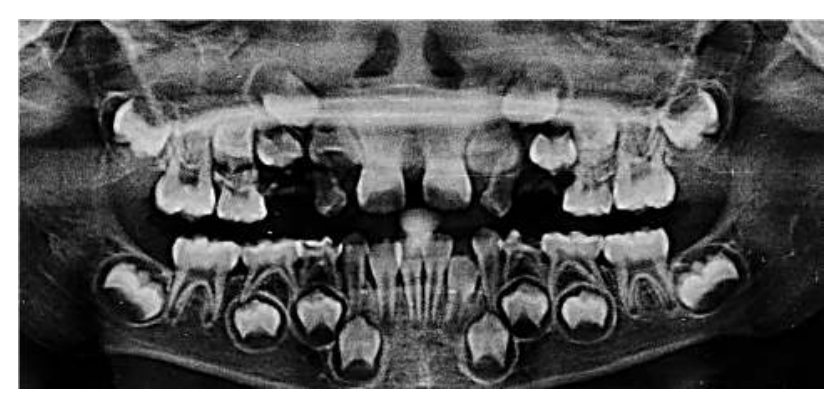

\begin{tabular}{ccc}
\hline Elemen Gigi & \multicolumn{1}{c}{ Tahapan Kalsifikasi Gigi } & Standar Blenkin \\
\hline M2 & C & 3 \\
M1 & F & 6 \\
P2 & D & 4 \\
P1 & D & 4 \\
C & D & 4 \\
I2 & F & 6 \\
I1 & G & 7 \\
\hline \multicolumn{3}{c}{ Total Skor Maturasi } \\
\hline \multicolumn{3}{c}{ Prakiraan Usia } \\
\hline \multicolumn{3}{c}{ Selisih Usia }
\end{tabular}

HASIL

A

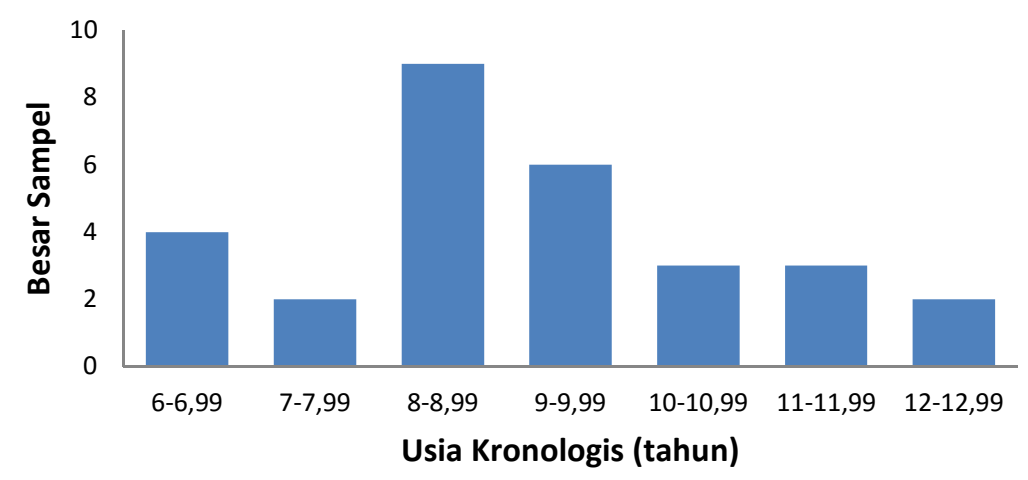

B

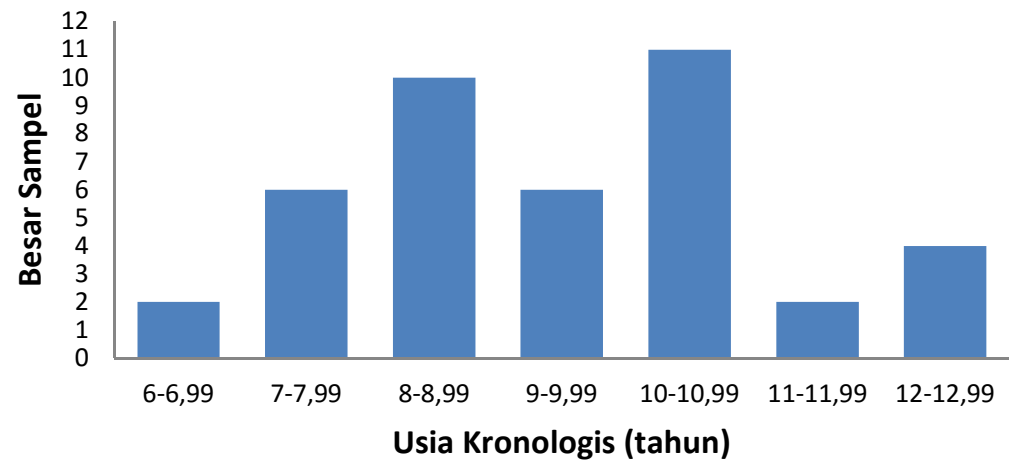

Gambar 3. Distribusi besar sampel pada anak-anak laki-laki (A) dan anak-anak perempuan(B) 


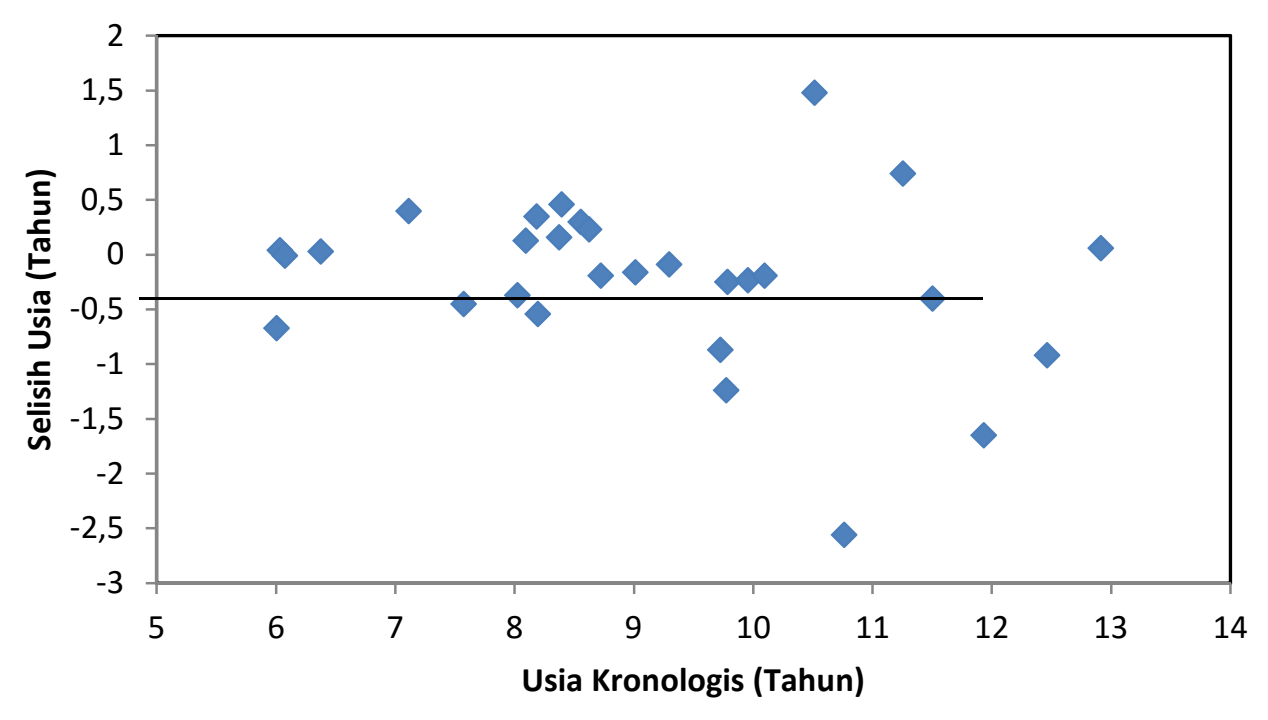

Gambar 4. Distribusi selisih usia antara usia kronologis dan usia gigi pada sampel anak-anak laki-laki menggunakan standar Blenkin

Tabel 2. Hasil Uji T-Test antara Usia Kronologis dan Usia Gigi pada Anak Laki-Laki Menggunakan Standar Blenkin

\begin{tabular}{|c|c|c|c|c|c|c|}
\hline \multicolumn{2}{|c|}{ Kelompok Usia } & \multicolumn{3}{|c|}{ Rerata ( $\pm S D$ ) } & \multirow{2}{*}{$\begin{array}{c}95 \% \mathrm{Cl} \text { dari } \\
\text { Perbedaan Usia }\end{array}$} & \multirow{2}{*}{ Nilai pt } \\
\hline Kategori & $\mathrm{n}$ & Usia Kronologis & Usia Gigi & Perbedaan Usia & & \\
\hline $6-6,99$ & 4 & $6,12(0,17)$ & $5,96(0,45)$ & $-0,15(0,34)$ & $-0,70 ; 0,39$ & 0,443 \\
\hline $7-7,99$ & 2 & $7,34(0,32)$ & $7,31(0,27)$ & $-0,02(0,60)$ & $-5,42 ; 5,37$ & 0,963 \\
\hline $8-8,99$ & 9 & $8,35(0,24)$ & $8,41(0,48)$ & $0,06(0,34)$ & $-0,20 ; 0,32$ & 0,623 \\
\hline $9-9,99$ & 6 & $9,59(0,36)$ & $9,11(0,45)$ & $-0,47(0,47)$ & $-0,96 ; 0,01$ & 0,056 \\
\hline $10-10,99$ & 3 & $10,45(0,34)$ & $10,03(1,89)$ & $-0,42(2,03)$ & $-5,46 ; 4,61$ & 0,753 \\
\hline $11-11,99$ & 3 & $11,56(0,34)$ & $11,12(0,85)$ & $-0,44(1,19)$ & $-3,40 ; 2,53$ & 0,592 \\
\hline $12-12,99$ & 2 & $12,68(0,32)$ & $12,25(1,01)$ & $-0,43(0,69)$ & $-6,65 ; 5,79$ & 0,541 \\
\hline $6-12,99$ & 29 & $9,08(1,89)$ & $8,86(1,85)$ & $-0,22(0,75)$ & $-0,50 ; 0,06$ & 0,125 \\
\hline
\end{tabular}

$\mathrm{n}$, jumlah sampel; SD, standar deviasi; $\mathrm{Cl}$, confidence Interval; $\mathrm{pt}=$ paired t-test

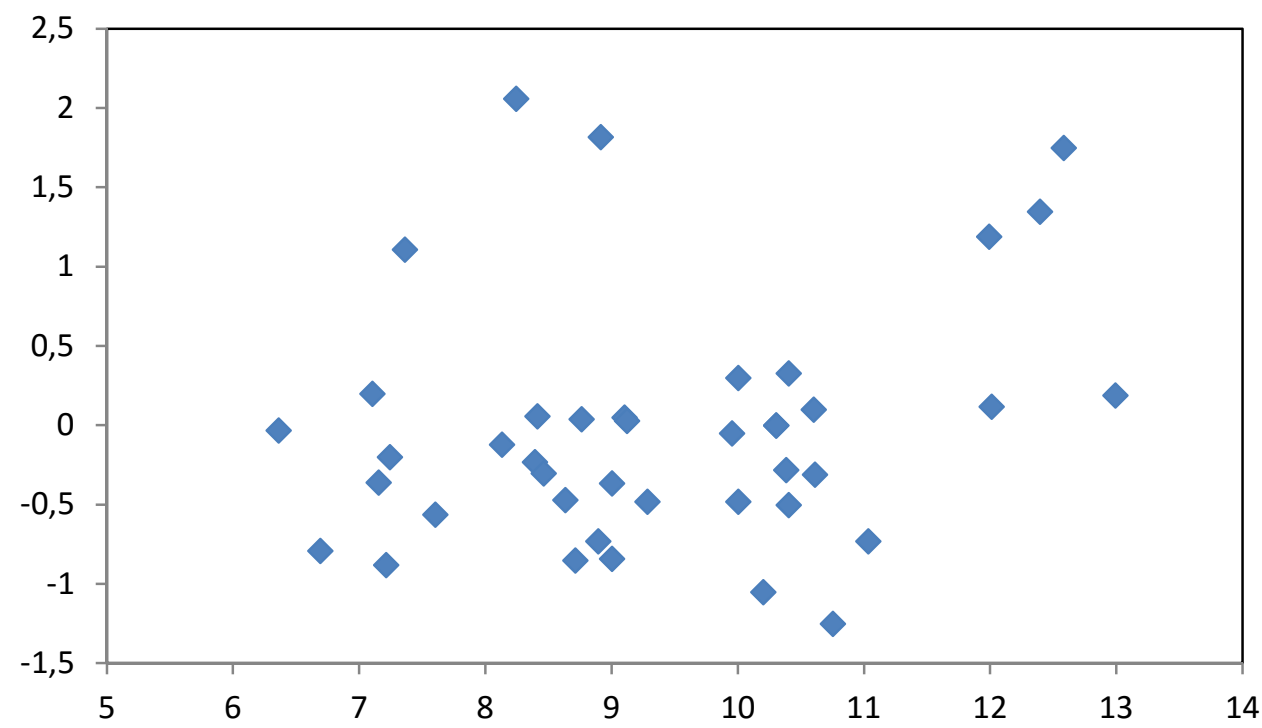

Gambar 5. Distribusi selisih usia antara usia kronologis dan usia gigi pada sampel anak-anak perempuan menggunakan standar Blenkin 
Tabel 3. Hasil Uji T-Test antara Usia Kronologis dan Usia Gigi pada Anak Perempuan Menggunakan Standar Blenkin

\begin{tabular}{ccccccc}
\hline \multicolumn{2}{c}{ Kelompok Usia } & \multicolumn{3}{c}{ Rerata (士SD) } & $\begin{array}{c}95 \% \text { Cl dari } \\
\text { Perbedaan Usia }\end{array}$ & Nilai pt \\
\hline Kategori & $\mathbf{n}$ & Usia Kronologis & Usia Gigi & Perbedaan Usia & \\
\cline { 1 - 5 } $6-6,99$ & 2 & $6,52(0,23)$ & $6,11(0,30)$ & $-0,41(0,54)$ & $-5,23 ; 4,41$ & 0,476 \\
$7-7,99$ & 6 & $7,28(0,18)$ & $7,16(0,72)$ & $-0,11(0,70)$ & $-0,84 ; 0,61$ & 0,704 \\
$8-8,99$ & 10 & $8,55(0,27)$ & $8,68(1,00)$ & $0,13(1,00)$ & $-0,58 ; 0,844$ & 0,696 \\
$9-9,99$ & 6 & $9,24(0,36)$ & $8,96(0,59)$ & $-0,27(0,35)$ & $-0,64 ; 0,09$ & 0,113 \\
$10-10,99$ & 11 & $10,36(0,24)$ & $10,07(0,50)$ & $-0,28(0,51)$ & $-0,42 ; 0,11$ & 0,235 \\
$11-11,99$ & 2 & $11,51(0,68)$ & $11,74(2,04)$ & $0,23(1,36)$ & $-11,96 ; 12,42$ & 0,850 \\
$12-12,99$ & 4 & $12,49(0,41)$ & $13,34(0,94)$ & $0,85(0,82)$ & $-0,45 ; 2,16$ & 0,130 \\
$6-12,99$ & 41 & $9,38(1,67)$ & $9,35(1,99)$ & $-0,03(0,77)$ & $-0,27 ; 0,21$ & 0,816 \\
\hline
\end{tabular}

Hasil penelitian dari penilaian usia gigi pada sampel anak-anak etnik Jawa di Jember menggunakan standar Blenkin beserta hasil analisis statistiknya disajikan dalam bentuk data gambar dan tabel. Besar sampel yang digunakan dalam penelitian ini adalah 70 sampel yang terdiri dari 29 sampel anak-anak laki-laki dan 41 sampel anak-anak perempuan. Usia sampel berkisar antara 612,99 tahun. Besar sampel terbanyak untuk sampel anak-anak laki-laki adalah 9 sampel yang diperoleh pada kelompok usia 8-8,99 tahun, sedangkan besar sampel terbanyak untuk sampel anak-anak perempuan adalah 11 sampel yang diperoleh pada kelompok usia 10-10,99 tahun (gambar 3, 4 dn table 2 .

Gambar 4 menunjukkan distribusi selisih usia antara usia kronologis dan usia gigi pada sampel anak-anak laki-laki menggunakan standar Blenkin. Sebagian besar nilai menunjukkan prakiraan usia gigi yang kurang dari usia kronologisnya untuk semua kelompok usia.

Tabel 2 menunjukkan tidak terdapat perbedaan yang signifikan penilaian usia gigi pada sampel anak laki-laki usia 6-12,99 menggunakan standar Blenkin dengan ratarata selisih usia sebesar $-0,22(S D=0,75)$ dan nilai signifikansi sebesar 0,125 . Nilai negatif selisih usia menunjukkan bahwa nilai usia gigi kurang dari usia kronologisnya. Selisih usia negatif terdapat pada kategori usia 6-6.99, 77.99, 9-9.99, 10-10.99, 11-11.99, dan 12-12.99.

Gambar 5 menunjukkan distribusi selisih usia antara usia kronologis dan usia gigi pada sampel anak-anak perempuan menggunakan standar Blenkin. Sebagian besar nilai menunjukkan prakiraan usia gigi yang kurang dari usia kronologisnya untuk semua kelompok usia.

Tabel 3 menunjukkan tidak terdapat perbedaan yang signifikan penilaian usia gigi pada sampel perempuan usia 6-12,99 menggunakan standar Blenkin dengan ratarata usia $-0,03(S D=0,77)$ dan nilai signifikansi sebesar 0,816. Nilai negatif selisih usia menunjukkan bahwa nilai usia gigi kurang dari usia kronologisnya. Selisih usia negatif terdapat pada kategori usia 6-6.99, 7-7.99, 99.99, dan 10-10.99.

\section{PEMBAHASAN}

Blenkin merupakan salah satu peneliti yang telah melakukan penyesuaian terhadap metode Demirjian untuk diterapkan pada populasi anak-anak Sidney Australia. Hasil penelitian ini diperoleh perbedaan usia gigi rata-rata sebesar $-0,22$ tahun untuk sampel anak laki-laki dan -0,03 tahun untuk sampel anak perempuan. Meskipun selisih usia tersebut kecil, namun hampir terdapat pada seluruh kelompok usia. Bahkan terdapat selisih usia 0 pada 2 sampel anak perempuan. Selisih usia tersebut yang negatif $(-)$ menunjukkan bahwa usia gigi anak-anak etnik jawa lebih lambat dibandingkan dengan usia kronologisnya. Adanya perbedaan selisih usia gigi yang kecil pada seluruh kelompok usia baik pada sampel laki-laki dan sampel anak perempuan menunjukkan adanya variasi di dalam kelompok etnik jawa. Adanya kontrol genetik disebut-sebut memiliki peran yang besar dalam menentukan variasi antar individu dalam sebuah populasi.' Faktor lain yang dapat mempengaruhi proses kalsifikasi gigi manusia adalah faktor ekologi. Perbedaan iklim antara di daerah SidneyAustralia dengan iklim di daerah JemberIndonesia dimungkinkan mempunyai peran dalam menimbulkan variasi maturasi gigi meskipun variasinya kecil. Faktor ekologi dapat merubah waktu perkembangan dan adaptasi bagian tubuh tertentu yang memiliki peran dalam menjaga proses homeostasis tubuh ${ }^{6}$ dan menghasilkan variasi pertumbuhan sebuah populasi/ etnik. ${ }^{2}$ Faktor fisik seperti suhu dan kelembapan mempunyai pengaruh pada pertumbuhan melalui respon adaptasi terhadap lingkungan dan menginduksi perubahan pada metabolisme tubuh manusia. 7.8 Faktor-faktor fisik menginduksi adaptasi dan perubahan biologis manusia dan meningkatkan variasi biologis berupa perubahan struktur dan kemampuan fisiologis dalam merespon lingkungan.9.10,11 Perubahan atau respon biologis mempunyai peran dalam pengaturan waktu pertumbuhan dan menghasilkan maturasi yang terlambat jika kondisi ekologi tidak optimum. Terdapat penelitian pendahuluan mengenai hubungan antara pertumbuhan gigi dengan faktor ekologi seperti nutrisi, stress biologis, waktu kehamilan, 
kelembapan, suhu, dan faktor fisik dan sifatsifat lainnya yang menunjukkan hasil gradien positif dan korelasi yang tinggi antara kondisi kelembapan dengan waktu maturasi gigi. ${ }^{2}$

Faktor lain yang menyebabkan standar Blenkin lebih akurat adalah kemungkinan adanya kesamaan ras. Standar Blenkin yang penerapannya pada populasi SidneyAustralia yang multiras memungkinkan memiliki kesamaan ras dengan etnik Jawa yaitu ras Mongoloid. Dalam sensus yang dilakukan oleh Sidney Statistical Division tahun 2006, populasi penduduk Sydney mayoritas berasal dari Australia, Inggris, Irlandia, Skotlandia dan Cina. Sensus tersebut juga mencatat bahwa dua persen populasi Sydney adalah keturunan penduduk asli dan $31,7 \%$ diantaranya lahir di luar negeri. Penduduk Asia Australia berjumlah $16.9 \%$. Tiga negara sumber utama imigran adalah Britania Raya, Cina dan Selandia Baru, diikuti oleh Vietnam, Lebanon, India, Italia dan Filipina. Dalam hal ini peneliti berasumsi bahwa terdapat penduduk Sidney yang berasal dari negara-negara asia tersebut yang menjadi sampel penelitian dalam penelitian Blenkin. Populasi Cina, Vietnam dan Filipina merupakan populasi yang termasuk ras Mongoloid. Oleh karenanya dimungkinkan adanya ras Mongoloid dalam sampel penelitian Blenkin. Kesamaan inilah yang membuat standar Blenkin lebih akurat diterapkan pada etnik Jawa dibandingkan standar Demirjian. ${ }^{12}$

Penerapan standar Blenkin pada anakanak etnik Jawa di Jember menghasilkan prakiraan usia gigi yang berbeda tidak bermakna. Penerapan standar Blenkin menghasilkan prakiraan usia gigi yang sesuai yaitu sebesar $-0,22$ tahun untuk sampel anak laki-laki dan -0,03 tahun untuk sampel anak perempuan.

\section{DAFTAR PUSTAKA}

1. Blenkin, M., \& Taylor, J. Age estimation charts for a modern Australian population. Forensic international 2012; 221(1-3): 106-112.

2. Liversidge, H. M. Interpreting group differences using Demirjian's dental maturity method. Forensic science international 2010; 201 (1-3): 95-101.
3. Demirjian A, Goldstein H, Tanner J. A new system of dental age assessment. Hum Biol.1973; 45: 211-21

4. Panchbhai, A. S. Dental radiographic indicators, a key to age estimation. Dentomaxillofacial Radiology 2011; 40(4): 199-212.

5. Ali Bagherian and Mostafa Sadeghi. 2011. Assesment of dental maturity of children aged 3.5 to 13.5 years using the Demirjian method in an Iranian population. Journal of Oral Science, $2011 ; 53(1): 37-42$.

6. Graham, J. H., \& Özener, B. Fluctuating asymmetry of human populations: a review. Symmetry 2016; 8(12): 154.

7. Stock, J. T., Bazaliiskii, V. I., Goriunova, O. I., Savel'ev, N. A., \& Weber, A. W. 9. Skeletal Morphology, Climatic Adaptation, and Habitual Behavior among Mid-Holocene Cis-Baikal Populations. In Prehistoric huntergatherers of the Baikal region, Siberia. 201.University of Pennsylvania Press:193216

8. Betti, L., \& Manica, A. Human variation in the shape of the birth canal is significant and geographically structured. Proceedings of the Royal Society B 2018; 285(1889): 20181807.

9. Wu, X., Lu, Y., Zhou, S., Chen, L., \& Xu, B. Impact of climate change on human infectious diseases: Empirical evidence and human adaptation. Environment international 2016; 86: 14-23.

10. Scheday, S., Boenecke, J., Gogoi, A., Maharaj, A., \& Korovou, S. Climate change, health and mosquito-borne diseases: Trends and implications to the pacific region. International journal of environmental research and public health 2019;16(24): 5114 .

11. Frisancho, A. R. The study of human adaptation. Human evolutionary biology 2010; 17-28.

12. Australian Bureau of Statistics. Sydney Statistical Division in Census QuickStats. 2016. 